\title{
Ethanolysis of calabash (Lageneria sinceraria) seed oil for the production of biodiesel
}

\author{
Muhammad Mukhtar ${ }^{1}$, Chika Muhammad ${ }^{1}$, Musa Usman Dabai ${ }^{1}$, Muhammad Mamuda ${ }^{2}$ \\ ${ }^{1}$ Department of Pure and Applied Chemistry, Usmanu Danfodiyo University, P. M. B, 2346, Sokoto, Nigeria \\ ${ }^{2}$ Sokoto Energy Research Centre, Usmanu Danfodiyo University, P. M. B, 2346, Sokoto, Nigeria
}

Email address:

mmukhtar02@gmail.com (M. Mukhtar)

To cite this article:

Muhammad Mukhtar, Chika Muhammad, Musa Usman Dabai, Muhammad Mamuda. Ethanolysis of Calabash (Lageneria sinceraria)

Seed Oil for the Production of Biodiesel. American Journal of Energy Engineering. Vol. 2, No. 6, 2014, pp. 141-145.

doi: $10.11648 /$ j.ajee.20140206.13

\begin{abstract}
Biodiesel production from plant seed oil and animal fat is not a new technologies, though recently searching for alternative renewable sources of fuel is receiving much attention due to global energy demand and increase in environmental pollution. Currently biodiesel is largely produced from edible oil feedstock which may not be sustainable in the longer term due to its competition with food, thus lead to a search for not edible oil feedstock for the production of green fuel. In view of this, homogeneous transesterification of Lageneraria sinceraria seed oil has been carried out using $\mathrm{NaOH}$ catalyst at $65^{\circ} \mathrm{C}$ with ethanol which produced a good biodiesel yield of $78 \%$ with $\mathrm{HHV}$ of $36.34(\mathrm{MJ} / \mathrm{Kg}), 0.02 \%$ low total water and sediment level, $0.80 \mathrm{~g} / \mathrm{cm}^{3}$ density, $0.82 \mathrm{~g} / \mathrm{cm}^{3}$ specific gravity, $27.20 \mathrm{~g} / \mathrm{cm}^{3}$ API gravity, $0.44 \mathrm{mg}$ $\mathrm{NaOH} / \mathrm{g}$ Acid number and $144^{\circ} \mathrm{C}$ Flash point. The ethyl ester biodiesel produced, therefore, promises to be a viable source of energy for future use.
\end{abstract}

Keywords: Ethyl Ester, Quality Parameters, HHV, Lageneraria Sinceraria, Seed Oil

\section{Introduction}

Depletion of the world's petroleum reserves, increase in environmental pollution and increase in demand of energy due industrialization and population lead to search of alternative renewable sources of fuels [1, 2, 3, 4]. Globally transport sector has the highest rate in green house gases emissions $\left(20 \% \mathrm{CO}_{2}\right)$ in the last ten years[5] and it was projected to increases by $60 \%$ by year 2030 due to increase in higher energy use and carbon emission[6]. The world focus now is to produce energy from low carbon sources which is environmentally friendly [7], and thus the production of transportation fuels from renewable sources of energy is one of the most important challenges for the sustainable development [8].

Liquid transport biofuels are predominantly produced from biomass which is renewable, sustainable, biodegradable, carbon neutral and environmentally friendly [9]. Thus biodiesel is a renewable alternative source of energy which is non-toxic, biodegradable, with low carbon and particulate matter emissions compared to petroleumbase diesel and carbon dioxide produced by combustion of biodiesel can be recycled by photosynthesis and has become a popular and environmental friendly alternative fuel $[10,11]$.

Biodiesel is an alternative fuel which can be produced from different mechanisms such as transesterification process, in which mono alkyl ester compound of long chain fatty acid is produced when alcohol, such as methanol or ethanol, in the present of acid or base catalyst chemically react with triglycerides (vegetable oils or animal fats), which can be used in compression ignition engines for energy generation [9, 12, 13]. Recently homogeneous transesterification with $\mathrm{NaOH}$ and $\mathrm{KOH}$ catalyst is major technologies involved in production of biodiesel [14]

Developing countries such as Nigeria have a comparative advantage for biofuel production because of greater availability of land, favourable climatic conditions for agriculture and lower labour costs [15], but yet many of the present problems of Nigeria are closely related to the problem of energy distribution. Energy plays a vital role in the economic, social and welfare development of any nation, insufficient supply of energy restricts socio economic growth and adversely affects the quality of life [16]. The rising cost of petroleum products and climate change is a problem facing many developing countries and solution to this problem can be found in the explorations of 
renewable or alternative energy resources and one of such alternate energy source in transport sector is biodiesel which can prepared from triglycerides $[17,18]$.

Biodiesel is an important fuel option for rural and urban populace, it is relatively easy to manufacture, renewable and has better lubricating and environmental properties than mineral diesel $[19,20]$. Biodiesel production is an important component of a combined strategic approach to diversify the sources of fuels, reduce green house gases emission to the environment, decrease current total dependence on fossil fuels and also serve as a tool for poverty reduction through job creation to the timming populace.

In biodiesel production, it is preferable to use available local raw materials for the country where biodiesel plant will be installed [21], therefore, exploration of local renewable resource of energy such as calabash (Lageneria sinceraria) seed oil, produced from north-western Nigeria, is of great important. Lagenaria siceraria is a climbing ornamental plant which is largely cultivated in the northern Nigeria, it grown as shrub with its fruit hanging on a flat bed and its fruits usually harvested between 90 to 120 days after planting. Calabash is majorly used in rural settlement as container and storage vessels[22, 23]

The aim of this study is to explore the use of calabash (Lageneraria sinceraria) seed oil for the production of Biodiesel and to assess it biodiesel properties in order to compliment the effort of Nigerian government on biofuels research.

\section{Materials and Methods}

\subsection{Sampling}

The calabash (Lageneria sinceraria) seeds were purchased from the Sokoto Central Market, north-western

Nigeria and authenticated at the Biological Science department, Botany unit, Usmanu Danfodiyo University, Sokoto. The seeds were sorted out, dehulled, ground into powder and the oil was extracted using soxhlet extraction method using n-hexane solvent.

All the reagents used in these studies were of Analar grade and distilled water was used throughout the experiment.

\subsection{Experimental Procedure}

\subsection{Transesterification of the Oil}

A $500 \mathrm{~cm}^{3}$ 3-necked round bottom flask (set with thermometer, stirrer and condenser with guard tube to prevent moisture entering into the system) was heated to drive out residual moisture. On cooling, 175g of Lageneria sinceraria seed oil (crude grade) was added to the flask. The oil was stirred and heated in a water bath to $65^{\circ} \mathrm{C}$ at which freshly prepared sodium ethoxide $\left(40 \mathrm{~cm}^{3}\right.$ ethanol and $1 \mathrm{~g} \mathrm{NaOH}$ ) was added rapidly under stirring condition and the reaction continued for two hours at the same temperature. Two layers were observed clearly on cooling. The top layer was biodiesel and the bottom denser layer was glycerine. The top layer was neutralized by diluted acetic acid and washed with distilled water [24, 25].

The CHNS analyses were performed on the ethyl-ester biodiesel using FLASH 2000 Organic Elemental Analyser: $3.0 \mathrm{mg}$ of ethyl-ester biodiesel were weighed onto a tin sheet capsule with microbalance and equivalent amount of vanadium (v) oxide (as a source of oxygen) was added and sealed. BBOT $\{2,5$ - Bis (5 - tert-butyl-2-benzexazol-2-yl) Thiophene $\left.\left[\mathrm{C}_{26} \mathrm{H}_{26} \mathrm{~N}_{2} \mathrm{O}_{2} \mathrm{~S}\right]\right\}$ was used as a reference standard [26].

\section{Results and Discussion}

\subsection{Results}

Table 1. Biodiesel Quality Parameters.

\begin{tabular}{|c|c|c|c|c|}
\hline Parameters & Unit & Test Method & Calabash Seed oil Biodiesel & Limits \\
\hline Total $\mathrm{H}_{2} \mathrm{O}$ and sediment level & (v) $\%$ & D 2709 & 0.02 & $0.05 \max$ \\
\hline Density & $\mathrm{g} / \mathrm{cm}^{3}$ & D 7371-07 & 0.80 & $0.90 \max$ \\
\hline Specific gravity & $\mathrm{g} / \mathrm{cm}^{3}$ & D 7371-07 & 0.82 & $0.90 \max$ \\
\hline API gravity & $\mathrm{g} / \mathrm{cm}^{3}$ & D 7371-07 & 27.20 & $30-40$ \\
\hline Acid number & $\mathrm{mgKOH} / \mathrm{g}$ & D664 & 0.44 & $0.50 \max$ \\
\hline Flash Point & ${ }^{\circ} \mathrm{C}$ & D 93 & 144 & $130 \mathrm{~min}$ \\
\hline
\end{tabular}

The Quality assessments results was compared with biodiesel, ASTM limits reported by Gerpen et al., [27].

Table 2. FAEE CHNS Analysis

\begin{tabular}{llllll}
\hline [\%] C & H & N & S & O* & HHV [MJ/Kg] \\
\hline 73 & 10.1 & 4.4 & 0.2 & 12.3 & 36.4 \\
\hline
\end{tabular}

* indicate that Oxygen value was obtained by difference.

Boie equation $\mathrm{HHV}^{\mathrm{a}}[\mathrm{MJ} / \mathrm{kg}]=[351.60 \mathrm{C}+1162.25 \mathrm{H}-$ $110.90 \mathrm{O}+62.80 \mathrm{~N}+104.65 \mathrm{~S}] \times 10^{-3}$

\subsection{Discussion}

The Table 1 above shows the properties of the biodiesel produce and its various blends specified by the ASTM, which were examined based on B100 biodiesel.

\subsubsection{Water and Sediment Level}

The water and sediment level is an important industrial indicator of cleanliness of the fuel because water reacts with biodiesel to form free fatty acid and it may lead to microbial growth in storage tank and can contribute to filter 
plugging and fuel injection system wear [27,28]. Higher level of water content lead to severe corrosion of fuel system components and reduce the heat of combustion [28]. Water and sediment was found to be $0.02 \%$ which agreed with the ASTM standard of $0.05 \%$ maximum volume [27]. The result indicates that ethyl biodiesel produced is clean and may not form free fatty acid due to hydrolysis [29] and may reduce the microbial growth during storage [27].

\subsubsection{Densities, Specific and API Gravities}

Densities, specific and API gravities were found to be $0.80 \mathrm{~g} / \mathrm{cm}^{3}, 0.82 \mathrm{~g} / \mathrm{cm}^{3}$ and $27.20 \mathrm{~g} / \mathrm{cm}^{3}$ respectively and all the values are within the ASTM limits of biodiesel [27]. These values must be within tolerable limits to allow optimum air to fuel ratio for complete combustion [30] because high density biodiesel or its blends can leads to incomplete combustion and particulate matter emission .The results, therefore, indicate that biodiesel produced from $\mathrm{NaOH}$-ethanolysis of Lageneria sinceraria seed oil may undergo complete combustion and produce less particulate matter. The lower density of ethyl biodiesel produced in this research may be due to its degree of unsaturation or chain length $[31,32]$.

\subsubsection{Acid Number}

The acid number is an important fuel property; it is a measure of free fatty acids in a given product. [28], Acid number of the biodiesel produced from Lageneria sinceraria seed oil indicates that it contains higher fatty acid composition of $0.44 \mathrm{mgKOH} / \mathrm{g}$ but is within the acceptable range ( $0-0.50$ max) specified by the ASTM [27]. This result indicates that ethyl ester biodiesel produced may not cause severe corrosion in internal combustion engine and fuel system [28].

\subsubsection{Flash Point}

Flash point is another important fuel property and is the temperature at which fuel will ignite when exposed to flame. Biodiesel usually has high (more than $150^{\circ} \mathrm{C}$ ) flash point than petroleum diesel $\left(55-66^{\circ} \mathrm{C}\right)$ [28]. Flash point is not directly related to engine performance but is inversely related to fuel volatility [30], it is controlled to meet safety requirement for fuel handling, storage and transportation[33]. The $144{ }^{\circ} \mathrm{C}$ value obtained is in agreement with ASTM biodiesel standard (130 ${ }^{\circ} \mathrm{C}$ min) [34] and result revealed that the biodiesel produced contain low volatile impurities (majorly ethanol) [32] and can be useful in arctic region [27].

\subsubsection{Ultimate Analysis}

Table 2 gives the ultimate analysis of Lageneria sinceraria seed oil ethyl ester biodiesel, the results show low sulphur content of $0.2 \%$ which may cause low sulphur oxides emission during combustion [28], high nitrogen content of $4.4 \%$ which may lead to the formation of $\mathrm{NOx}$ during fuel combustion [35], and high oxygen content of $12.3 \%$ which may reduce the particulate emission during fuel combustion. The heating value is an important parameter in the selection of fuel [28] and estimation fuel consumption, and determines the energy content of fuel. The greater heating value (HHV) of a fuel, the lower the fuel consumption and vice versa[36,37]. The produced ethyl ester biodiesel of Lageneria siceraria seed oil shows slightly higher energy content of $36.34 \mathrm{MJ} / \mathrm{Kg}$ as compared to the $35.56 \mathrm{MJ} / \mathrm{Kg}$ of Pongamia pinnata (Karanja) biodiesel [38]. Usually biodiesel calorific value is lower than that of conventional diesel due to its high oxygen content [30]

\section{Conclusion}

The ethyl ester biodiesel produced from Lageneria sinceraria seed oil has acceptable properties approved by the American Society of Testing Materials (ASTM) and National Biodiesel Board (NBB) with high energy content. The high nitrogen content balanced with high oxygen content may reduce the particulate emission during fuel combustion while high acid value may be reduced by the use of acid pre-treatment such as neutralization before oil transesterification. The use of ethyl biodiesel from Lageneria sinceraria seed oil as a transport fuel in the future will, therefore, drastically reduce the overwhelming energy crisis and carbon dioxide emissions in both developed and developing countries of the world.

\section{References}

[1] A.B.M.S. Hossain and A. Salleh, Biodiesel fuel production from Algae as renewable energy, American Journal of Biochemistry and Biotechnology, 4 (3): 250-254, (2008).

[2] B. R. Dhar and K. Kirtania, Excess methanol recovery in biodiesel production process using a distillation column: A simulation study, Chemical Engineering Research Bulletin, 13; Pp. 55-60, (2009).

[3] Y.C. L. Dennis, X. Wu and M.K.H. Leung, a review on biodiesel production using catalyzed transesterification, Applied Energy, 87: Pp. 1083-1095, (2010).

[4] D.Y.C., Leung, X, Wu and M.K.H., Leung, A review on biodiesel production using catalyzed Transesterification, Applied Energy, 87:Pp. 1083-1095, (2010).

[5] R. Luque, L. Herrero-Davila, J. M. Campelo, J. H. Clark, J. M. Hidalgo, D. Luna, J. M. Marinasa and A. A. Romero, Biofuels: a technological perspective, Energy \& Environmental Science, 1(5); Pp. 513-596, (2008).

[6] B. Metz, O. R. Davidson, P. R. Bosch, R. Dave and L. A. Meyer, IPCC, Climate change 2007: Mitigation, Contribution of working group 3 to the Fourth Assessment Report of the Intergovernmental Panel on Climate Change,Cambridge University Press, Cambridge, United Kingdom and New York, USA, (2007).

[7] A.P. S. Chouhanand A.K., Sarma, Modern heterogeneous catalysts for biodiesel production:A comprehensive review, Renewable and Sustainable Energy Reviews, 15: Pp. 4378 4399, (2011). 
[8] W. D. Huang and Y. H. P. Zhang, Analysis of biofuels production from sugar based on three criteria: Thermodynamics, bioenergetics, and product separation, Energy\& Environmental Science,4:Pp.784-792, (2011).

[9] N.N.A.N. Yusuf, S.K. Kamarudinand, Z. Yaakub, Overview on the current trends in biodiesel production, Energy Conversion and Management,52, Pp. 2741-2751, (2011).

[10] Y. Zhang, M.A. Du, D.D. McLean and M. Kates, Review Paper; Biodiesel production from waste cooking oil: Process design and technological assessment, Bioresource Technology, 89 ,1-16, , (2003).

[11] R. Wang, W. W, Zhou, M. A. Hann, Y. P. Zhang, P. S. Bhadury, Y. Wang, B. A. Song and S. Yang, Biodiesel preparation, optimization, and fuel properties from nonedible feedstock, Daturastramonium L. Fuel, 91, Pp.182186, (2012).

[12] O. S. Valente, V. M. D. Pasa, C. R. P. Belchior and J. R. Sodré, Physical-chemical properties of waste cooking oil biodiesel and castor oil biodiesel blends, Fuel, 90, Pp. 1700-1702, (2011).

[13] G. Hincapié, F. Mondragón and D., López, Conventional and in situ transesterification of castor seed oil for biodiesel production, Fuel 90, Pp. 1618-1623, (2011).

[14] H.V. Lee, J.C. Juan a Y.H. Taufiq-Yap,(2015), Preparation and application of binary acid-base $\mathrm{CaO}-\mathrm{La}_{2} \mathrm{O}_{3}$ catalyst for biodiesel production, Renewable Energy, 74:Pp. 124132(2015)

[15] M. Balat, Potential alternatives to edible oils for biodiesel production - A review of current work, Energy Conversion and Management, 52, Pp. 1479-1492, (2011).

[16] B. Garbaand A.M. Bashir, Managing energy in Nigeria: Study on energy consumption pattern in selected Rural Areas in Sokoto State. Nigeria Journal of Renewable Energy, 10. (1\&2):97-107, (2002).

[17] B. Garba and U. P. Ojukwu, Biodegradation of water Hyacinth as an alternative source of fuel: A review. Journal of Renewable Energy, 6 (1\&2): Pp.12-15, (1999).

[18] N. K. Sahoo, A. K. Satyawati and S.N. Naik, Interaction of Jatropha curcas plantation with ecosystem: proceedings of international conference on energy and Enviroment: Pp. 19-21, (2009).

[19] T. Whittington, Biodiesel Production and use by farmers: is it worth considering? Department of agriculture and food, government of western Australia, available at: http://www.bebioenergy.com/documents/Onfarmbiodieselpr od.pdf accessed on 10/03/2013, (2006).

[20] B. R. Moser, and S. F. Vaughn, Efficacy of fatty acid profile as a tool for screening feedstocks for biodiesel production, Biomass and Bioenergy, 3 7, Pp.31-41, ( 20012 ).

[21] A. Anastasov, Biodiesel-Basic characteristics, technology and perspectives, Biotecnol\&Biotechnol Anniversary scientific conference, available online at www.diagnosisp.com/dp/journals/view pdf.php?...id... Accessed on 14/03/2013, (2009).

[22] O. Olaofe, H.N Ogungbenle, B.E Akhadelor, A.O Idris, O.V , O.T Omotehinse and O.A Ogunbodede, Physico chemical and fatty acids composition of oils from some legume seeds, International Journal of Biological, Pharmacy and Allied Science, 1(3): 355-363,(2012)

[23] N. A., Sani , L. G., Hassan, S. M., Dangoggo , M. J., Ladan, I. Ali-baba and K.J. Umar, Effect of Fermentation on the Nutritional and Antinutritional Composition of Lagenaria Siceraria Seeds, Journal of Applied Chemistry, 5( 2): Pp. 01-06, (2013).

[24] S. Puhan, N. Vedaraman, V.B, Boppana, G. Ram, Sankarnarayanan and Jeychendran, Mahua Oil (MadhucaIndica Seed Oil) methyl ester as biodiesel: preparation and emission characteristics. Biomass and Bioenergy, 28:87 - 93,(2005).

[25] S. S. Rahayu and A. Mindaryani, Methanolysis of Coconut Oil: the kinetic of heterogeneous reaction, Proceedings of the world congress on engineering and $\mathrm{c}$ omputer science 2009, Vol I, WCECS 2009, October 20-22, 2009, San Francisco,USA, available online at;http://www.iaeng.org/publication/WCECS2009/WCECS2 009 pp134-138.pdf, Accessed on 14/03/2013, (2009).

[26] Mukhtar, M. Dangoggo, S.M. and Ross,A.B. (2012),Low Temperature/Pressure Hydrothermal Microwave as a Potential Alternative Method of Processing Microalgae, Proceeding of the 35th Chemical Society of Nigeria, Annual and International Conference, 1, Pp. 510-515.

[27] J.V. Gerpen, B. Chanks, R. Pruszo, D. Clements and G. Knoth, Biodiesel Analytical Methods Subcontractor Report, National Renewable Energy Laboratory. August, 2002January, 2004, NREL/SR-510-36240, available at; $\mathrm{http}: / /$ www.bentlybiofuels.com/pdfs/NREL_BD_Analytical. pdf accessed on 16/01/2012, (2004).

[28] A. E Atabani, A. S. Siltonga, H. C Ong, T.M.I. Mahila and H.H. Masjuki, Non-edible vegetable oils: a critical evaluation of oil extraction, fatty acid compositions, biodiesel production, characteristics, engine performance and emissions production, renewable and sustainable energy review, 18; Pp. 211-245, (2013)

[29] S.K, Hoekmana, A, Broch. C., Robbins, E., Ceniceros, M., Natarajan, Review of biodiesel composition, properties and specifications, Renewable and sustainable Energy Reviews, 16. P. $143-169$, (2012)

[30] L.F. Ramirez-Verduzeo, J.E. Rodriguez-Rodriguez, A.R. Jaramillo-Jacob, Predicting cetene number, kinematic viscosity, density and higher heating value of biodiesel from its fatty acid methyl ester composition, Fuel, 91, P. 102-111, (2012)

[31] A. Javidialesaadi and S. Raeissi, Biodiesel production from higher free fatty acid content oils: experimental investigation of the pretreatment step, APCBEE procedia,5; Pp. 474-478, (2013)

[32] P. Sexena, S. Jawale and M. Joshipura, A review on prediction of properties of biodiesel and blends of biodiesel, Procedia Engineering, 51; Pp. 395-402, (2013)

[33] K. Sivaramakrishnan and P. Ravikumar, Determination of Cetane number of biodiesel and its influence on physical properties, ARPN Journal of Engineering and Applied Sciences, 7( 2):Pp. 205-211,(2012)

[34] I.M. Atadashi, M.K. Aroua, A.R. Abdul Aziz and N.M.N. Sulaiman, (2011),Refining technologies for the purification of crude biodiesel, Applied Energy, $88: 4239-4251$ 
[35] Ross, A.B. and Biller, P. (2011), Potential yields and properties of oil from the hydrothermal liquefaction of microalgae with different biochemical content, Bioresource Technology, 102: Pp. 215-225.

[36] Knothe, G. (2008). "Designer" Biodiesel: Optimizing fatty ester composition to improve fuel properties. Ener. Fuels 22: $1358-1364$.
[37] K. Sivaramakrishnan and P. Ravikumar, Determination of higher heating value of biodiesels, International Journal of Engineering Science and Technology, 3 (11):Pp. 79817987,(2011)

[38] S. A Karmee and A. Chadha, preparation of biodiesel from crude oil of Pongamia Pinnata, Bioresource technology, 96(13); Pp. 1425- 1429, (2005). 